\title{
Season-long ammonia flux measurements above fertilized corn in central Illinois, USA, using relaxed eddy accumulation
}

\author{
Andrew J. Nelson ${ }^{\mathrm{a}, \mathrm{b}}$, Sotiria Koloutsou-Vakakis ${ }^{\mathrm{a}, *}$, Mark J. Rood ${ }^{\mathrm{a}}$, LaToya Myles ${ }^{\mathrm{c}}$, \\ Christopher Lehmann $^{\mathrm{d}}$, Carl Bernacchi ${ }^{\mathrm{e}, \mathrm{f}}$, Srinidhi Balasubramanian ${ }^{\mathrm{a}}$, Eva Joo ${ }^{\mathrm{e}}$, \\ Mark Heuer $^{\mathrm{g}}$, Marcelo Vieira-Filho ${ }^{\mathrm{h}}$, Jie Lin ${ }^{\mathrm{a}}$ \\ a Department of Civil and Environmental Engineering, University of Illinois at Urbana-Champaign, 205 North Mathews Avenue, Urbana, IL 61801-2352, USA \\ ${ }^{\mathrm{b}}$ U.S. Army Corps of Engineers, Engineer Research and Development Center, Construction Engineering Research Laboratory, Champaign, IL 61822, USA \\ c National Oceanic and Atmospheric Administration, Air Resources Laboratory, Atmospheric Turbulence and Diffusion Division, Oak Ridge, TN 37831-2456, \\ USA \\ d National Atmospheric Deposition Program, Illinois State Water Survey, 2204 Griffith Drive, Champaign, IL 61820-7495, USA \\ e Department of Plant Biology and the Energy Biosciences Institute, University of Illinois at Urbana-Champaign, 1206 West Gregory Drive, Urbana, IL \\ 61801, USA \\ f USDA-ARS Global Change and Photosynthesis Research Unit, Urbana, IL 61801, USA \\ g ORAU Assigned to the National Oceanic and Atmospheric Administration, Air Resources Laboratory, Atmospheric Turbulence and Diffusion Division, Oak \\ Ridge, TN 37831-2456, USA \\ ${ }^{\mathrm{h}}$ Departamento de Engenharia, Universidade Federal de Lavras, Campus da UFLA, 37200-000, Lavras, Minas Gerais, Brazil
}

\section{A R T I C L E I N F O}

\section{Article history:}

Received 30 September 2016

Received in revised form 17 February 2017

Accepted 16 March 2017

\section{Keywords:}

$\mathrm{NH}_{3}$ flux

Maize

Corn canopy

Midwest USA

Relaxed eddy accumulation (REA)

\begin{abstract}
A B S T R A C T
The objective of this research is to quantify $\mathrm{NH}_{3}$ flux above an intensively managed cornfield in the Midwestern United States to improve understanding of $\mathrm{NH}_{3}$ emissions and evaluations of new and existing emission models. A relaxed eddy accumulation (REA) system was deployed above a corn canopy in central Illinois, USA $\left(40^{\circ} 3^{\prime} 46.209^{\prime \prime} \mathrm{N}, 88^{\circ} 11^{\prime} 46.0212^{\prime \prime} \mathrm{W}\right)$ from May through September 2014 (day of year 115-273) to measure $\mathrm{NH}_{3}$ fluxes due to chemical fertilizer application. $\mathrm{NH}_{3}$ flux was measured in fourhour periods during mornings and afternoons. Mean atmospheric $\mathrm{NH}_{3}$ concentration during the complete measurement period was $2.6 \pm 2.0 \mu \mathrm{g} \mathrm{m}{ }^{-3}$. Larger upward fluxes of gaseous $\mathrm{NH}_{3}$ were measured during the first 30 days after fertilization, with variations observed throughout the field campaign. Measured $\mathrm{NH}_{3}$ fluxes ranged from $-246.0 \mathrm{ng} \mathrm{m}^{-2} \mathrm{~s}^{-1}$ during wintertime background measurements to $799.6 \mathrm{ng} \mathrm{m}^{-2} \mathrm{~s}^{-1}$ within two weeks of fertilization (where negative flux indicates deposition). Mean positive flux was $233.3 \pm 203.0 \mathrm{ng} \mathrm{m}^{-2} \mathrm{~s}^{-1}$ in the morning and $260.0 \pm 253.3 \mathrm{ng} \mathrm{m}^{-2} \mathrm{~s}^{-1}$ in the afternoon while mean negative flux was $-45.3 \pm 38.6 \mathrm{ng} \mathrm{m}^{-2} \mathrm{~s}^{-1}$ in the morning and $-78.35 \pm 74.9 \mathrm{ng} \mathrm{m}^{-2} \mathrm{~s}^{-1}$ in the afternoon. $\mathrm{NH}_{3}$ volatilization during the first 21 days after fertilization accounted for $79 \%$ of total nitrogen loss during the growing season. Such measurements are critical to improve understanding of agricultural $\mathrm{NH}_{3}$ emissions in managed agricultural ecosystems dominated by rotations of highly fertilized corn and moderately to lightly fertilized soybeans, such as the plot studied herein. These measurements are also important to improve understanding of how managed agricultural ecosystems impact air quality, and contribute to the global nitrogen cycle, and to evaluate current $\mathrm{NH}_{3}$ emission models.
\end{abstract}

(c) 2017 Elsevier B.V. All rights reserved.

\footnotetext{
* Corresponding author.

E-mail address: sotiriak@illinois.edu (S. Koloutsou-Vakakis).
}

\section{Introduction}

\subsection{Atmospheric ammonia}

The atmosphere plays an important role in redistributing reactive nitrogen $(\mathrm{Nr})$ around the globe through transport, transformation, and deposition (Galloway et al., 2008). Increased demand for food and use of fossil fuels for energy production have resulted in perturbation of the nitrogen cycle, contributing to adverse human

http://dx.doi.org/10.1016/j.agrformet.2017.03.010

0168-1923/C 2017 Elsevier B.V. All rights reserved.

(C) 2017. This manuscript version is made available under the Elsevier user license

http://www.elsevier.com/open-access/userlicense/1.0/ 
health effects and degradation of natural and managed ecosystems (Erisman et al., 2013).

Anthropogenic $\mathrm{NH}_{3}$ is introduced to the environment by chemical fertilizer application, residential and industrial fuel combustion, livestock waste generation, industrial processes, and waste disposal (USEPA, 2011). Agricultural activities (i.e., livestock waste and chemical fertilizer usage) are the primary emission sources of $\mathrm{NH}_{3}$ to the atmosphere. According to United States Environmental Protection Agency's (USEPA's) National Emission Inventory (NEI) estimates, concentrated animal feed operations (CAFOs) and chemical fertilizer use accounted for $62 \%$ and $31 \%$, respectively, of anthropogenic $\mathrm{NH}_{3}$ emissions in the USA, in 2011 (USEPA, 2015). The relative source contribution of atmospheric $\mathrm{NH}_{3}$ varies regionally (Cooter et al., 2010). In Illinois, where the major cultivated crops are corn and soybean, the 2011 contribution to emissions from chemical fertilizer usage was 54\% (USEPA, 2015). Volatilization of $\mathrm{NH}_{3}$ from fertilized agricultural fields to the atmosphere causes adverse human health and environmental effects and is a lost economic input (Conant et al., 2013).

$\mathrm{NH}_{3}$ is a precursor for secondary particulate matter (PM) in the atmosphere. $\mathrm{PM}_{10}$ and $\mathrm{PM}_{2.5}$ (PM with diameters $\leq 10 \mu \mathrm{m}$ and $\leq 2.5 \mu \mathrm{m}$, respectively) are of regulatory interest because of their health effects (USEPA, 2012) and contribution to visibility degradation (Green et al., 2012). Deposition of $\mathrm{NH}_{3}$ or its secondary products can have detrimental effects to plants depending on ecosystem characteristics and nutrient availability (Mattsson et al., 2008). Vegetation in natural and intensively managed ecosystems can act as both a source and a sink of $\mathrm{NH}_{3}$ (Nemitz et al., 2001). Atmospheric deposition of $\mathrm{NH}_{3}$ can promote soil acidification and exacerbate water quality and eutrophication problems in aquatic ecosystems (Erisman et al., 2013).

Measurements of $\mathrm{NH}_{3}$ emissions to the atmosphere from anthropogenic activities are important for understanding the links among emission sources and transformation and fate of $\mathrm{NH}_{3}$ in the atmosphere (Galloway et al., 2008). $\mathrm{NH}_{3}$ emissions from the use of chemical fertilizers in agriculture are not well quantified (Bash et al., 2010; Walker et al., 2013), limiting the ability to accurately predict environmental and economic impacts. This uncertainty also affects the quality of evaluations of models designed to predict $\mathrm{NH}_{3}$ emissions (Paulot et al., 2014; Balasubramanian et al., 2015), secondary pollutant formation (Gilliland et al., 2006), deposition of nitrogen species (Appel et al., 2011), and estimation of anthropogenic climate forcing (Myhre et al., 2013).

\subsection{Measurement of atmospheric ammonia flux}

Measurement of trace gaseous atmospheric $\mathrm{NH}_{3}$ fluxes is challenging (Sutton et al., 2007). $\mathrm{NH}_{3}$ is a reactive basic gas that readily adheres to surfaces such as wet leaves and soil. Further, $\mathrm{NH}_{3}$ and $\mathrm{NH}_{4}{ }^{+}$(together referred to as $\mathrm{NH}_{\mathrm{X}}$ ) often exist simultaneously in the gaseous, particulate, and aqueous phases, where partitioning varies with environmental conditions such as temperature and relative humidity (Norman et al., 2009). This has led to the development of many different $\mathrm{NH}_{3}$ measurement techniques, including enclosure and micrometeorological methods (Norman et al., 2009).

Micrometeorological methods for flux measurement include the flux-gradient method (Duyzer, 1994), eddy flux/eddy covariance (Baldocchi et al., 1988), eddy correlation (Desjardins, 1972), and Relaxed Eddy Accumulation (REA) (Businger and Oncley, 1990). When compared to enclosure methods, micrometeorological methods have the advantage that they capture spatially averaged land-atmosphere gaseous exchange over large areas $\left(>100 \mathrm{~m}^{2}\right.$ ) without disturbing ambient conditions (Sommar et al., 2013). However, such methods are limited by the assumption of homogeneity of the surface, stationary turbulence, and adequate fetch (Fotiadi et al., 2005).
Flux-gradient and eddy flux/eddy covariance approaches require the availability of a precise ( $\pm 10 \%$ precision), fast-response (e.g., $10 \mathrm{~Hz}$ ) sensor to measure concentration of the constituent of interest (Phillips et al., 2004). Fast-response instruments for measurement of $\mathrm{NH}_{3}$ concentration are not readily available for use under ambient field conditions (Hensen et al., 2009), though a research-grade open path eddy-covariance instrument has been described in the literature (Sun et al., 2015). The eddy correlation and REA methods are attractive for the quantification of $\mathrm{NH}_{3}$ fluxes because they do not rely on fast-response sensors to measure $\mathrm{NH}_{3}$ concentration (Myles et al., 2011). However, a drawback to these methods is that they are labor intensive, and temporal resolution is limited by the need to acquire adequate $\mathrm{NH}_{3}$ mass in the sampling reservoirs for quantification in the laboratory.

REA provides the ability to quantify trace gas fluxes based on conditional measurement of gas concentrations at a constant sample flow rate (Businger and Oncley, 1990). REA has been used to measure fluxes of trace gases to the atmosphere with temporal resolution on the order of hours when gas concentrations cannot be measured instantaneously (Baker et al., 1992). The REA method requires the use of an empirically derived REA coefficient $(\beta)$ to describe the relative contributions to flux of turbulent updrafts and downdrafts. The theoretical expectation of is 0.627 (Baker et al., 1992).

Measurements of $\mathrm{NH}_{3}$ flux over agricultural canopies in the USA with sub-daily temporal resolution are limited in geographic location and crop type. Studies include measurements over grassland (Myles et al., 2007; Myles et al., 2011), soybean (Walker et al., 2006), and forest canopies (Neirynck and Ceulemans, 2008). Despite the high fertilization rates and predominance of corn cultivation in the Midwestern USA, we have been able to find only one study of $\mathrm{NH}_{3}$ flux over corn in this region (Harper and Sharpe, 1995). Harper and Sharpe reported measurements of $\mathrm{NH}_{3}$ flux in Nebraska using $24 \mathrm{~h}$ to $48 \mathrm{~h}$ integrated samples. Though Nebraska and Illinois are located in the region defined as "Midwest" for census purposes, they belong to different climate regions, as defined in the National Climate Assessment (NCA) (USDOC-NOAA, 2013). Other studies of $\mathrm{NH}_{3}$ flux from corn canopies in the USA have been reported for a site in North Carolina (Walker et al., 2013; He et al., 2013) and Maryland (Meyers et al., 2006). Walker et al. (2013) studied $\mathrm{NH}_{3}$ fluxes during a 64-day period immediately after field fertilization, observing peak emissions and high variability in the first 31 days $\left(339.2 \pm 601.7 \mathrm{ng} \mathrm{m}^{-2} \mathrm{~s}^{-1}\right)$ followed by a lower, less variable emission profile $\left(61.4 \pm 10.2 \mathrm{ng} \mathrm{m}^{-2} \mathrm{~s}^{-1}\right)$.

\subsection{Research motivation and significance}

In this paper, we present results from a study to quantify above canopy $\mathrm{NH}_{3}$ concentration and flux from fertilized corn in an intensively managed agricultural ecosystem in the Midwestern USA. The study was conducted for the entire 2014 corn-growing season (day of year, DOY, 115-273) using the REA method. Measurements were also made over fallow land in March 2015 to characterize background $\mathrm{NH}_{3}$ fluxes and concentrations after frost and before any fertilization activities. This research seeks to provide a better understanding of land-atmosphere $\mathrm{NH}_{3}$ exchange due to fertilized corn and to quantify such exchange in an environment where field management practices and their timing are highly variable. Emphasis was placed on the period from planting to peak leaf area index (LAI), an important under-measured period for $\mathrm{NH}_{3}$ emissions during crop development (Walker et al., 2013). The four-hour measurement interval used in this study provides improved information about shorter-term (<1 day) $\mathrm{NH}_{3}$ emission intensity from corn in the Midwestern USA. These measurements are important to improve understanding of how managed agricultural ecosystems 
impact air quality, contribute to the global nitrogen cycle, and to evaluate current $\mathrm{NH}_{3}$ emission models.

\section{Methods}

\subsection{Site description}

The field campaign took place during the 2014 corn-growing season at the University of Illinois at Urbana-Champaign (UIUC) Energy Biosciences Institute (EBI) Energy Farm in Urbana, IL USA. Illinois is located in the flat terrain geographical region known as the Midwestern USA and belongs to the Midwest NCA climate region. The lack of mountains and distance from the ocean $(>1000 \mathrm{~km})$ result in wide extremes of temperature and precipitation that can occur over days, weeks, months, and years, while all seasons have potential for high damaging winds (USDOC-NOAA, 2013). The Energy Farm (described by Zeri et al., 2011) was subdivided into four different $200 \mathrm{~m} \times 200 \mathrm{~m}$ research plots. Each plot was planted with one of either miscanthus, switchgrass, restored prairie, or corn, in 2014. The southeastern most plot of the Energy Farm, hereafter referred to as the study plot, was planted with corn and was the location for this research $\left(40^{\circ} 3^{\prime} 46.209^{\prime \prime} \mathrm{N}, 88^{\circ}\right.$ $11^{\prime} 46.0212^{\prime \prime} \mathrm{W}, 220 \mathrm{~m}$ above sea level). The study plot was serviced with two 20 A, 110 VAC circuits. Fig. 1 depicts the study plot's historical wind rose data and its neighboring fields.

Site selection was influenced by a number of factors: a) management practices at the study plot were representative of conventional farm management practices in the area (e.g., chisel plow tilling, fertilization, and herbicide application) and historical records dating to 2008 were readily available; b) on site meteorological data were available from 2009 through the 2014 growing-season from another study that used eddy covariance for measurements of $\mathrm{CO}_{2}$ and water vapor fluxes (described first in Zeri et al., 2011); c) ready access to the site was available for installation; and d) protection of instrumentation due to activities in the field was accommodated. Considering the fetch of the study plot (100-140 m), the scope of the study, logistics associated with $\mathrm{NH}_{3}$ flux sampling, and challenges with access to third party property, this study plot was selected as the best site to meet the objectives of this research.

Local point measurements of $\mathrm{NH}_{3}$ flux are important to improve understanding of processes that affect $\mathrm{NH}_{3}$ emissions from fertilization and to contribute to upscaling of such measurements to regional scales using models (Balasubramanian et al., 2015). When upscaling, uncertainties may be introduced due to uncertainties in inputs such as land use maps, soil maps, varying meteorology or lack of farm management data at the farm level (Balasubramanian et al., 2015). Taking this into account along with challenges accessing plots with larger footprints and the scarcity of $\mathrm{NH}_{3}$ flux measurements in the given region, we followed the rationale that as long as the primary footprint of measurements was over fields of fertilized corn, the goal of characterizing emissions from an intensively corn managed ecosystem was still met. In this research, that condition was fulfilled as the study plot was neighbored by a corn field $>900 \mathrm{~m}$ deep extending from $110^{\circ}<\theta<265^{\circ}$ in the predominant wind direction.

\subsection{Field management practices}

The study plot was planted with a corn-corn-soybean crop rotation from 2008 through 2014. Soybeans (variety Asgrow ${ }^{\circledR}$ A3555, Monsanto, St. Louis, MO) were cultivated at the study plot in 2013. Standard agricultural practices for central Illinois were used at the study plot. Diammonium phosphates, potash, and lime were applied using variable-rate technology to achieve the desired whole-farm soil fertility goal ( $\mathrm{pH}: 6.0 ; 50.4 \mathrm{~kg}-\mathrm{P}$ ha $^{-1} ; 336 \mathrm{~kg}-\mathrm{K}$ $\mathrm{ha}^{-1}$ ). The study plot was sprayed with $168 \mathrm{~kg}-\mathrm{N} \mathrm{ha} \mathrm{H}^{-1}$ as $28 \%$ ureaammonium nitrate (UAN) fertilizer containing a urease inhibitor $\left(\right.$ Agrotain $^{\circledR}$ ) and $7.0 \mathrm{~L} \mathrm{ha}^{-1}$ pre-emergent herbicide (Lumax ${ }^{\circledR}$, Syngenta: Basel, Switzerland), and immediately tilled, in the morning of May 6, 2014 (DOY 126). Corn (Dekalb ${ }^{\circledR}$ DKC64-69, Monsanto: St. Louis, MO) was machine-sown with $76 \mathrm{~cm}$ row spacing in the afternoon of May 6, 2014 at a seeded population of 86,000 plants ha ${ }^{-1}$. Hand planting was used around the sampling equipment at the center of the study plot. Herbicide (Roundup ${ }^{\circledR}$ Powermax, Monsanto: St. Louis, MO) was applied as needed to control grass and broadleaf weeds prior to emergence. The same herbicide was applied to the entire plot on June 6, 2014 (DOY 157) at $1.6 \mathrm{~L} \mathrm{ha}^{-1}$. The neighboring cornfield was fertilized with $201 \mathrm{~kg}^{-\mathrm{N} \mathrm{ha}}{ }^{-1}$ on March 26, 2014 (DOY $85 ; 33 \mathrm{~kg}-\mathrm{N} \mathrm{ha}{ }^{-1}$ as $28 \%$ UAN and $168 \mathrm{~kg}-\mathrm{N} \mathrm{ha}^{-1}$ as $82 \%$ anhydrous $\mathrm{NH}_{3}$ ) (personal communication with EBI Energy Farm manager).

\subsection{Ammonia concentration and flux}

The REA method for above-canopy $\mathrm{NH}_{3}$ flux measurement requires knowledge of the mean concentration of $\mathrm{NH}_{3}$ during updrafts and downdrafts, $\overline{C \uparrow}$ and $\overline{C \downarrow}$, respectively. Mean vertical flux, $\bar{F}$, is estimated using Equation 1:

$\bar{F}=\beta \sigma_{w}(\bar{C}-\overline{C \downarrow})$

where $\sigma_{w}$ is the standard deviation of the vertical wind velocity, overbars denote time averaging, and $\uparrow$ and $\downarrow$ denote up- and down-draft measurements, respectively. $\beta$ was estimated from measurements of sonic temperature using Equation (2).

$\beta=\frac{\overline{w^{\prime} T^{\prime}}}{\sigma_{w}\left(\overline{T^{\uparrow}}-\overline{T^{\downarrow}}\right)}$

where $w$ is vertical wind speed, $T$ is sonic temperature, and primes (') denote deviations from the mean. Use of sonic temperature is based on the assumption of scalar similarity, where $\mathrm{NH}_{3}$ is carried similarly to other scalars in the same turbulent eddies (Wyngaard and Coté, 1972).

A dynamic deadband threshold of $\pm 0.3 \sigma_{w}$ was calculated at $1 \mathrm{~Hz}$ using a 5 min rolling boxcar average of $\sigma_{w}$ to increase the difference between measured concentrations during updraft and downdraft conditions and reduce switching frequency of the valves (Bowling et al., 1999; Meyers et al., 2006). The deadband is a threshold value of vertical wind velocity that must be exceeded to trigger valve switching (Grönholm et al., 2008). Because the use of a dynamic deadband scales $\beta$ based on atmospheric conditions, it allows the REA system to compensate for changing atmospheric conditions that may occur during a multi-hour run (Grönholm et al., 2008).

The REA sampling system is shown in Fig. 2. Prior to corn emergence, measurement height, $z_{m}$, was $2.0 \mathrm{~m}$ to reduce the probability of soil aspiration in the denuder assemblies that were used to collect $\mathrm{NH}_{3}$. Measurement height was adjusted from $2.0 \mathrm{~m}$ to $4.5 \mathrm{~m}$ depending on canopy height $\left(h_{c}\right)$ to avoid overestimating source/sink contributions from any single canopy element (Raupach, 1994). LAI was measured weekly using a non-destructive plant canopy analyzer (model LAI-2200, LI-COR, Lincoln, NE).

A REA control box was used to control gas flow and switching denuders during updraft, downdraft, and deadband conditions. The control box was similar to the one described in (Meyers et al., 2006). Gas flow rate through the denuders was fixed at $20.0 \mathrm{~L} \mathrm{~min}^{-1} \mathrm{using}$ a mass flow controller (MFC) (model GFC371, Aalborg: Orangeburg, NY). All flow measurements are reported at standard conditions; $0{ }^{\circ} \mathrm{C}$ and $101.4 \mathrm{kPa}$. The MFC had a valid factory calibration and was tested regularly using a piston meter (model DryCal DC2, Bios: But- 

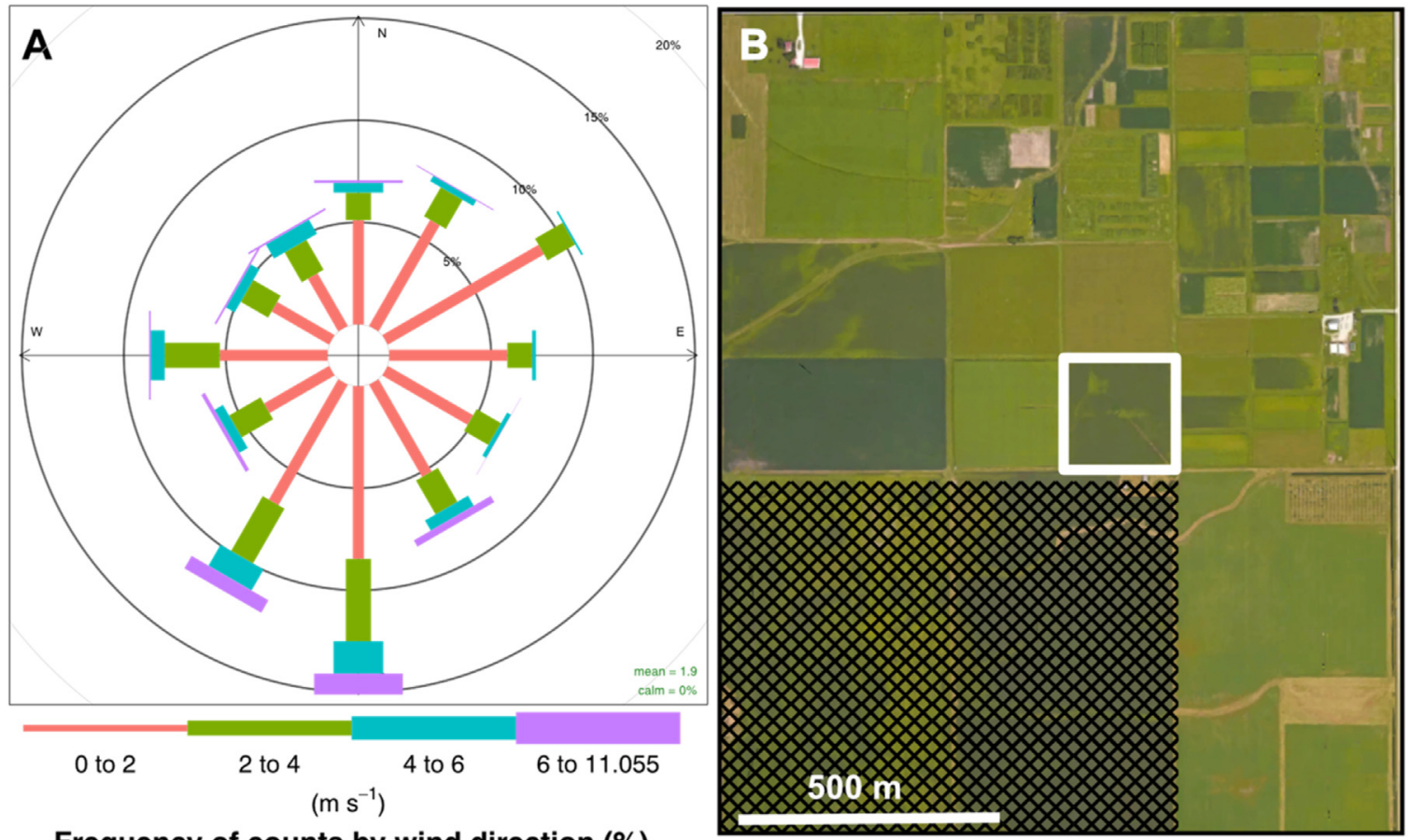

Frequency of counts by wind direction (\%)

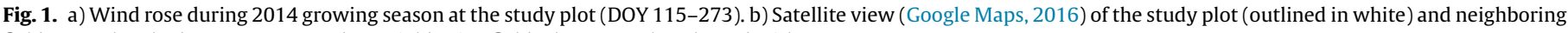
fields. Crosshatched areas correspond to neighboring fields that were also planted with corn.

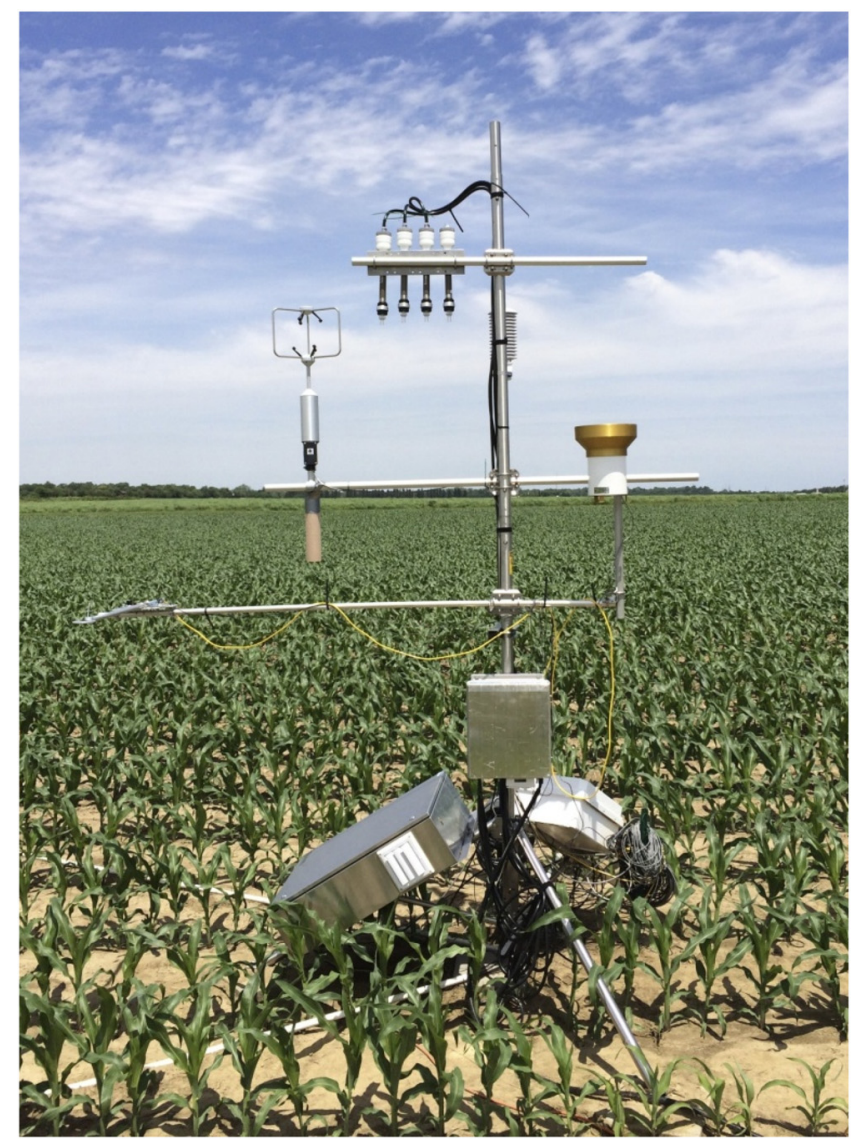

Fig. 2. REA sampling system (June, 2014). ler, NJ). An integrated logic board controlled switching of three solenoid valves (model 2W13W-9DB-A6C5, Snap-Tite Inc.: Erie, $\mathrm{PA})$, with a $10 \mathrm{~ms}$ response time. Gas flow was induced by a rotary vane vacuum pump (model 0523, Gast Manufacturing Inc.: Benton Harbor, MI). Emissions from the pump were controlled with an absolute particle filter.

The REA box was controlled by a field computer running the open source program SONIC.C (version 2.6.0, NOAA ATDD, SONIC program for Linux, Oak Ridge, TN) and was connected to a three-axis ultrasonic anemometer (model 81000 VRE, R.M. Young Company: Traverse City, MI). The anemometer measured wind speed in three directions $(u, v$, and $w)$ and sonic temperature $(T)$, at $10 \mathrm{~Hz}$. SONIC.C was used to correct the anemometer coordinate system.

Annular glass denuders (model URG-2000-30 × 242-3CSS, URG Corp: Chapel Hill, NC) were used to collect $\mathrm{NH}_{3}$ from the sampled air volume. Four denuders were used for each REA sampling run: one each for updraft, deadband, and downdraft conditions and one as a field blank. The field blank denuder assembly was not actively sampled, but the inlet was exposed to the atmosphere during the REA sampling run to quantify $\mathrm{NH}_{3}$ exposure caused by passive diffusion, advection, and denuder handling. Each denuder assembly included an upstream glass elutriator inlet (model URG-2000-30 K, URG Corp) to remove $\mathrm{PM}_{2.5}$ and a downstream two-stage $47 \mathrm{~mm}$ Teflon $^{\circledR}$ filter pack (model URG-2000-30FG, URG Corp) to protect the pump from particulate aspiration. The downstream ends of the denuder assemblies were connected to the REA control box using $6.35 \mathrm{~mm}$ inner diameter (ID) black polyvinyl chloride (PVC) tubing (McMaster Carr: Chicago, IL).

REA sampling runs were performed throughout the 2014 corngrowing season (as weather allowed) with focus on daily sampling during the first month after fertilization when peaks in $\mathrm{NH}_{3}$ emissions have been measured in experiments at a location in North Carolina (Walker et al., 2013). Sampling did not occur during precipitation events because the aspiration of water into the denuders would affect the measurement accuracy. Samples were collected 
as often as possible during the first 30 days following fertilization. The sampling plan for the remainder of the season was scheduled to align with growth stages V5, V10, V15, VT, R3, and R6 (UI, 2009). However, adjustments to this schedule were required due to precipitation events and high winds (resulting in large flux footprint).

Sample duration was guided by the analytical detection limit for $\mathrm{NH}_{4}{ }^{+}$and typical ambient $\mathrm{NH}_{3}$ concentrations in the area. REA runs occurred from 07:30-11:30 am and 12:00-16:00 pm local time. These times were selected to represent average daily meteorology and to avoid sampling during diurnal stability transitions at dawn and dusk. No nighttime samples were collected as the REA method is not expected to perform well in a stable boundary layer (Fotiadi et al., 2005).

\subsection{1. $\mathrm{NH}_{3}$ flux and concentration calculation}

Preparation and extraction of denuders followed the National Atmospheric Deposition Program (NADP) standard operating procedure (SOP) PR-4074 (NADP, 2012). Extracts were analyzed according to NADP SOP AN-0022 (NADP, 2008) by flow injection analysis (FIA) (Quik Chem 8000, Zellweger/Lachat Analytics, Inc.: Milwaukee, WI) with a detection limit of $3 \mu \mathrm{g}-\mathrm{NH}_{4}{ }^{+} \mathrm{L}^{-1}$ of extract solution. This is a colorimetric determination using indophenol as an indicator based on the Berthelot reaction.

$\mathrm{NH}_{3}$ concentration for each denuder $\left(\mathrm{C}_{\mathrm{NH}_{3} \text {-denuder }}\right)$ was calculated using Eq. (3).

$C_{\mathrm{NH}_{4}^{+} \text {-denuder }}=0.944 \frac{C_{\mathrm{NH}_{4}^{+}} V_{\text {extract }}}{V_{\mathrm{REA}}}$

where 0.944 is the ratio of the molecular weight of $\mathrm{NH}_{3}$ to $\mathrm{NH}_{4}^{+}$, $\mathrm{C}_{\mathrm{NH}_{4}^{+}}$is the concentration of $\mathrm{NH}_{4}^{+}$in the denuder extract solution, $V_{\text {extract }}$ is the volume of deionized water used during extraction, and $V_{R E A}$ is the total volume sampled through each denuder assembly. Knowing $\mathrm{C}_{\mathrm{NH}_{3} \text {-denuder }}$, for the up- and down-draft denuders, mean

$\mathrm{NH}_{3}$ flux during each sampling run $\left(\overline{\mathrm{FH}_{3}}\right)$ was calculated using Eq. (1). REA sampling runs were omitted from the results when $\beta$ differed from the population mean by more than three standard deviations. Ambient $\mathrm{NH}_{3}$ concentration $\left(\mathrm{C}_{\mathrm{NH}_{3}}\right)$ measured with the REA system was calculated with Eq. (3) by summing $\mathrm{C}_{\mathrm{NH}_{4}^{+}}$for each of the three actively sampled denuders. Laboratory and field blanks were used to screen for contamination in denuders.

We also collected ambient $\mathrm{NH}_{3}$ concentration data using passive samplers (model Radiello ${ }^{\circledR} 123-7$, Supelco: Bellefonte, PA), at the study plot. Passive samplers were used in accordance with NADP SOP SS-4070 for monitoring ambient $\mathrm{NH}_{3}$ on a biweekly time interval (NADP, 2013). We compared these results to results from the NADP-Ammonia Monitoring Network $(\mathrm{AMoN})$ Bondville monitoring site for the duration of this study (nadp.sws.uiuc.edu/data/AMoN/) to assess atmospheric $\mathrm{NH}_{3}$ concentration as measured by the REA system with a well-established monitoring site. The Bondville site is located $13 \mathrm{~km}$ west of the study plot in a similar intensively managed ecosystem characterized as a rural location surrounded by corn and soybean cropland. Coefficient of variation (CV) was used to quantify variability in the sample population, where $\mathrm{CV}$ is the absolute value of the ratio of the standard deviation to the mean.

\subsection{Analytical quality assurance/quality control}

All denuders were coated, extracted, and analyzed at the NADP Central Analytical Laboratory (CAL) by CAL staff according to NADP SOPs, as described earlier. CAL used validated quality assurance procedures to reduce the potential for contamination of denuders during preparation and extraction. Laboratory personnel wore two layers of gloves: one pair of latex-free vinyl gloves (model 19-041-
189, Fisher Scientific: Pittsburgh, PA) was put on first followed by one pair of polyethylene gloves (model Poly-D FoodMates, Ansell: Melbourne, Australia). These procedures have resulted in the least cross-contamination of $\mathrm{NH}_{3}$ due to individual body chemistry and chemical composition of gloves and bags (NADP, 2013).

All denuders and inlet assemblies were handled in a clean air hood (model PVLF-72, Air Science USA LLC: Fort Myers, FL) designed to provide an environment free of $\mathrm{NH}_{3}$ during preparation and extraction. $\mathrm{NH}_{3}$ concentration within the hood and the laboratory area was monitored using two-week integrated diffusive $\mathrm{NH}_{3}$ Radiello $^{\circledR}$ samplers to check for laboratory contamination. Coating, exposure, and extraction dates for all denuders and filter packs were tracked using sequentially numbered bar-code labels and the laboratory information management system.

Prepared elutriator-inlets, denuders, and filter packs were stored in low-density polyethylene (LDPE) plastic bags (series F4 Double Track, Elkay Plastics: Chicago, IL) at $4{ }^{\circ} \mathrm{C}$ until used. For every 20 denuders prepared, at least one denuder was maintained as a laboratory blank. The blank was prepared identically to those used in the field, but remained at $4{ }^{\circ} \mathrm{C}$ from when it was prepared until immediately before extraction and analysis to identify potential cross-contamination during the lab preparation and extraction process.

\subsection{Flux footprints and uncertainty estimation}

Flux footprints were calculated for each REA sampling run according to Kljun et al. (2004) using the EddyPro software package (Version 5.1.1, LI-COR: Lincoln, NE). This method requires that friction velocity $\left(u^{*}\right)$ exceeds a threshold value $\left(\mathrm{u}^{*} \geq 0.2 \mathrm{~ms}^{-1}\right)$, and the atmospheric stability parameter $(\zeta)$ falls within a certain range $(-200<\zeta<1)$. When these assumptions did not hold, the method by Kormann and Meixner (2001) was used because of its applicability to a wider range of atmospheric stability and friction velocity. Flux footprint was calculated for the $10 \%, 30 \%, 50 \%, 70 \%$, and $90 \%$ distances, where the NN\% distance corresponds to the determined footprint radius $(r)$ of the area that contributed NN\% of the total measured flux. For example, if $r=150 \mathrm{~m}$ for a $90 \%$ footprint distance, then $90 \%$ of the total measured flux was understood to originate from within a radius of $150 \mathrm{~m}$. For cases where the $90 \%$ footprint distance exceeded the $100 \mathrm{~m}$ study plot radius $\left(r_{S}\right)$ the relative fractional contribution to the measured flux from within $r_{S}$ was estimated by interpolation considering the $10 \%, 30 \%, 50 \%, 70 \%$, and $90 \%$ footprint distances.

The average wind direction $(\theta)$ was calculated for each REA sampling period and wind roses were generated in $\mathrm{R}$ ( $\mathrm{R}$ Core Team, 2013) using the OpenAir package (Version 0.9-2, Carslaw and Ropkins, 2012) run in RStudio (Version 0.98.501, RStudio Team, 2015). For cases where the $90 \%$ footprint distance exceeded $r_{S}$, visual inspection of wind roses was used to determine whether contributing sources to the measured flux from outside the study plot were corn fields or mixed crop types. Samples were removed from further statistics calculations if one of two conditions was met: 1) contribution from within $r_{S}$ was less than $50 \%$ and 2 ) the footprint contained crops other than fertilized corn.

Sommer and Jensen (1994) found the highest rate of $\mathrm{NH}_{3}$ volatilization from fertilized soils occurred within the first 5-10 days following fertilization using wind tunnel studies. Hence, we expect that the highest fluxes from all fertilized fields will occur during the period immediately following fertilization (i.e. one to two weeks). Because the neighboring field was fertilized 40 days before the study plot, we expect that positive flux from the neighboring field will be relatively lower than the study plot immediately following fertilization of the study plot on DOY 126 . To quantify the impact of such differences on our measurements, we estimated emissions from the study plot $\left(E_{S}\right)$ and the neighboring cornfield 


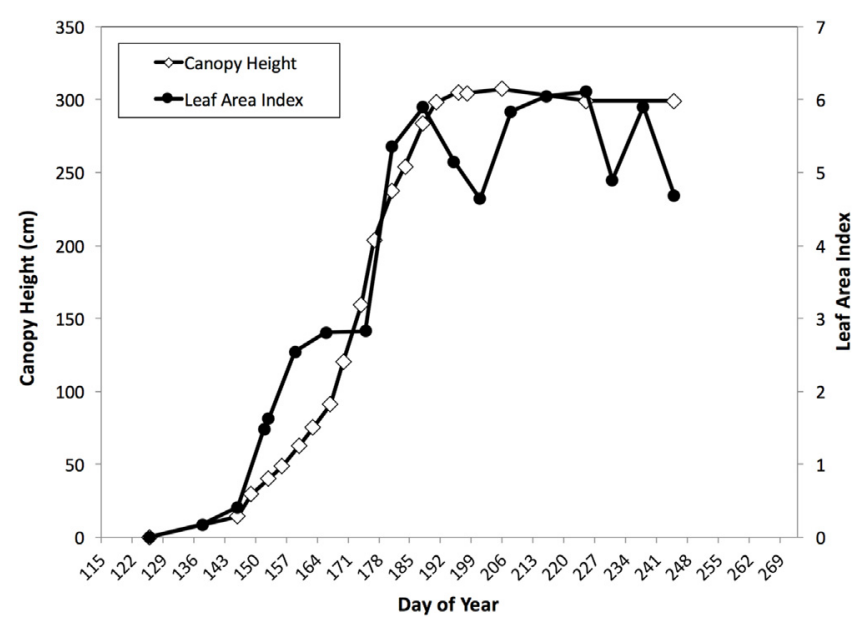

Fig. 3. Canopy height (left axis) and leaf area index (LAI; right axis).

$\left(E_{N}\right)$ using the DeNitrification DeComposition (DNDC) model (Li, 2000; Balasubramanian et al., 2015). We calculated the percentage of emission underestimation $\left(E_{u n d}\right)$ due to the difference in fertilization dates using Eq. (4):

$E_{\text {und }}=\frac{E_{S} * R_{S}+E_{N} * R_{N}}{E_{S}}$

where $R_{S}$ and $R_{N}$ are the relative fractional contributions to the measured flux from within the study plot and the neighboring plot respectively. A parallel study has been completed to examine closure between $\mathrm{NH}_{3}$ flux measurements and predictions from the DNDC model (Balasubramanian et al., 2017). That study has shown that the model captures satisfactorily the spatial and temporal variability of $\mathrm{NH}_{3}$ fluxes, as a function of environmental parameters and crop management practices.

\section{Results and discussion}

\subsection{Canopy development}

Plants were first visible on May 12 (DOY 132), six days after planting. Peak canopy height of $308 \mathrm{~cm} \pm 10 \mathrm{~cm}$ was observed on July 25 (DOY 206). The mature canopy LAI was 6.1, measured on August 13 (DOY 225). The study plot was harvested on November 6 (DOY 310) with an average yield of 13.78 ton ha ${ }^{-1}\left(219.5\right.$ bu acre $^{-1}$ ). Canopy development, as characterized by height and cumulative LAI is presented in Fig. 3.

The decreased values of LAI observed on DOY 195 and DOY 201 are attributed to heavy rain and thunderstorms that caused damage to the canopy structure, followed by low temperatures contributing to slow canopy recovery. The Illinois State Water Survey (ISWS) reported heavy thunderstorms and $11.0 \mathrm{~cm}$ of rain in ChampaignUrbana, IL on DOY 192-193, followed by additional rain $(1.3 \mathrm{~cm})$ on DOY 196 and abnormally low high temperatures $\left(21.1-26.1^{\circ} \mathrm{C}\right)$ for DOY 196-201 (ISWS, 2016).

\subsection{Ammonia concentration and flux measurements}

Results from the 39 REA sampling runs are presented in Table 1. Standard deviation of vertical wind speed $\left(\sigma_{w}\right)$, average and maximum wind speed ( $u_{\text {avg, }}$, and $u_{\text {max }}$, respectively), $\theta, C_{\mathrm{NH}_{3}}, \mathrm{NH}_{3}$ flux

$\left(\overline{F_{N H 3}}\right), \beta$, peak footprint contribution distance (x_peak), and $10 \%$, $30 \%, 50 \%, 70 \%$, and $90 \%$ flux footprint distances are presented as average values for each REA sampling period. REA sampling runs are identified by DOY followed by -1 or -2 to denote morning and afternoon runs, respectively.

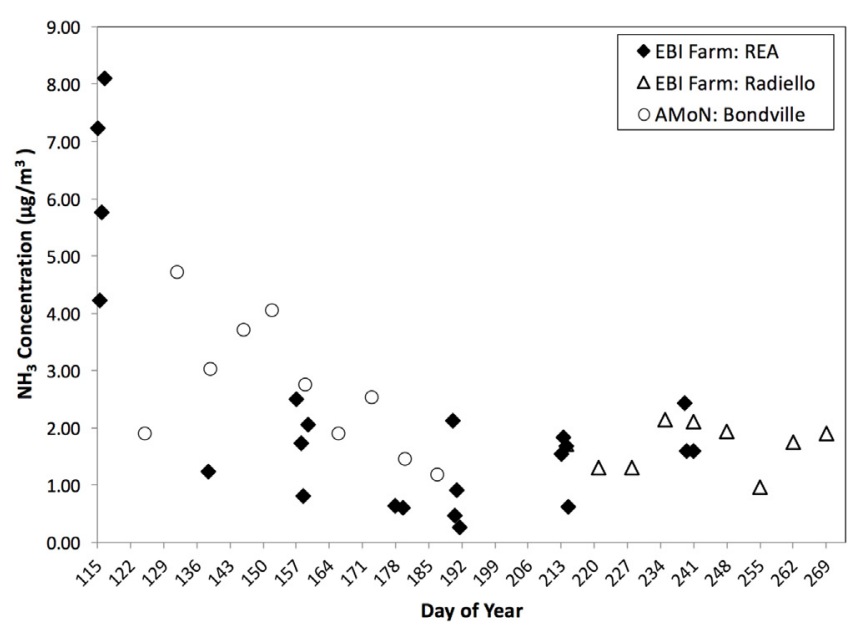

Fig. 4. $\mathrm{NH}_{3}$ concentration as measured using the REA system at the Energy Farm and passive Radiello samplers at the Energy Farm, and from the National Atmospheric Deposition Program (NADP) Ammonia Monitoring Network (AMoN) sampling site at Bondville, IL for DOY 115-273. Passive sampling occurred over two-week sampling periods.

One sample (DOY 126-2) was removed from further consideration based on the value of $\beta$. The observed mean and standard deviation of $\beta$ was $0.58 \pm 0.12$, consistent with the theoretical expectation and other measurements presented in the literature (Table 2).

Season average and standard deviation (DOY 115-273) of $\mathrm{C}_{\mathrm{NH}_{3}}$ from the REA system was $2.6 \pm 2.0 \mu \mathrm{g} \mathrm{m}^{-3} . \mathrm{C}_{\mathrm{NH}_{3}}$ measured using the REA system (for combined updraft, deadband, and downdraft conditions), Radiello ${ }^{\circledR}$ passive samplers at the study plot, and Radiello ${ }^{\circledR}$ passive samplers at the AMoN site in Bondville, IL, are presented in Fig. 4 for DOY 115-248 in 2014.

A high degree of variability was observed, with $C_{\mathrm{NH}_{3}}$ ranging from $0.26 \mu \mathrm{g} \mathrm{m}^{-3}$ on July 10 (DOY 191) to $8.11 \mu \mathrm{g} \mathrm{m}^{-3}$ on April 26 (DOY 116). This range is narrower than reported observations between $0.30-61.2 \mu \mathrm{g} \mathrm{m}^{-3}$ over a corn canopy at Lillington, NC, studied by Walker et al. (2013). Across all reported measurements, the REA denuder samples exhibited the highest CV of 0.776 , compared to $C V=0.463$ for the passive samplers at the study plot, and $\mathrm{CV}=0.308$ for the AMoN Bondville site. The higher variability of measurements from the REA system is attributed to the shorter averaging time $(4 \mathrm{~h})$ when compared to the passive samplers (biweekly), thereby allowing the REA system to $\mathrm{C}_{\mathrm{NH}_{3}}$ more readily capture temporal variation in $\mathrm{C}_{\mathrm{NH}_{3}}$.

A common trend in results from all three $C_{\mathrm{NH}_{3}}$ sampling methods was that the highest concentrations occurred during the beginning of the growing season (i.e. before June 1, DOY 152) when agricultural fertilization was occurring. Mean and standard deviation values for $\mathrm{C}_{\mathrm{NH}_{3}}$ for the first two weeks following fertilization at the study plot from the REA system were $4.56 \pm 1.96 \mu \mathrm{g} \mathrm{m}^{-3}$ while mean and standard deviation values for the remainder of the season were $1.46 \pm 0.69 \mu \mathrm{g} \mathrm{m}^{-3}$. Such overall temporal trends described here are consistent with experimental observations elsewhere (e.g., Walker et al., 2013).

Following a similar trend to that observed in $\mathrm{C}_{\mathrm{NH}_{3}}, \mathrm{NH}_{3}$ fluxes were highest and immediately following fertilization and planting (DOY 127-159). The remaining samples (DOY 160-273) had smaller $\mathrm{NH}_{3}$ flux values, including ten measurements of negative flux, indicating deposition to the surface (not including background measurements in March, 2015). Mean values of $\mathrm{NH}_{3}$ flux, $\beta$, and $\zeta$ for each REA sampling run are presented in Fig. 5. Measurements removed from further statistical consideration due to footprint considerations are identified with light gray fill and an asterisk next to the date on the $\mathrm{x}$-axis in Fig. 5. 
Table

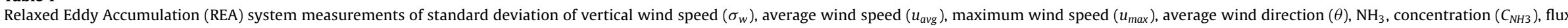

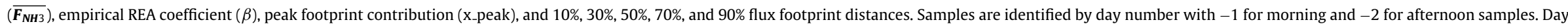
445 corresponds to March 21, 2015.

\begin{tabular}{|c|c|c|c|c|c|c|c|c|c|c|c|c|c|c|c|}
\hline Day & Start (HH:MM) & End (HH:MM) & $\sigma_{w}\left(\mathrm{~ms} \mathrm{~s}^{-1}\right)$ & $u_{\text {avg }}\left(\mathrm{m} \mathrm{s}^{-1}\right)$ & $u_{\max }\left(\mathrm{m} \mathrm{s}^{-1}\right)$ & $\theta(\mathrm{deg})$ & $C_{N H 3}\left(\mu \mathrm{g} \mathrm{m}^{-3}\right)$ & $F_{N H 3}\left(\mathrm{ng} \mathrm{m}^{-2} \mathrm{~s}^{-1}\right)$ & $\beta$ & $x_{\text {_peak }}(\mathrm{m})$ & $x_{-} 10 \%(\mathrm{~m})$ & $x \_30 \%(\mathrm{~m})$ & $x \_50 \%(\mathrm{~m})$ & $x_{-} 70 \%(\mathrm{~m})$ & $x_{-} 90 \%(\mathrm{~m})$ \\
\hline $115-1$ & $8: 10$ & $12: 01$ & 0.52 & 7.40 & 13.16 & 318 & 7.22 & -198.44 & 0.55 & 106.0 & 36.4 & 90.6 & 138.1 & 193.7 & 290.2 \\
\hline $115-2$ & $12: 33$ & $16: 38$ & 0.48 & 6.89 & 12.21 & 290 & 4.23 & 973.80 & 0.55 & 107.0 & 36.7 & 91.5 & 139.5 & 195.6 & 293.1 \\
\hline $116-1$ & 8:04 & $12: 11$ & 0.27 & 2.19 & 5.68 & 245 & 5.75 & -99.16 & 0.58 & 99.8 & 36.4 & 87.4 & 133.3 & 188.7 & 294.4 \\
\hline $116-2$ & $12: 21$ & $16: 24$ & 0.33 & 2.86 & 7.22 & 70 & 8.11 & 634.30 & 0.60 & 95.5 & 34.6 & 83.2 & 126.9 & 179.2 & 276.4 \\
\hline $126-2$ & $17: 27$ & $19: 40$ & 0.50 & 4.89 & 9.56 & 121 & 0.88 & -70.61 & -1.19 & 62.7 & 21.5 & 53.6 & 81.8 & 114.7 & 171.8 \\
\hline $127-1$ & $7: 47$ & $11: 57$ & 0.45 & 6.03 & 10.91 & 203 & 2.20 & 399.27 & 0.55 & 66.4 & 22.8 & 56.7 & 86.5 & 121.4 & 181.8 \\
\hline $127-2$ & $12: 10$ & $16: 19$ & 0.54 & 6.38 & 12.44 & 180 & 3.75 & 275.72 & 0.57 & 67.2 & 23.1 & 57.4 & 87.6 & 122.9 & 184.1 \\
\hline $128-1$ & $8: 02$ & $12: 05$ & 0.51 & 7.54 & 13.44 & 200 & 3.38 & 284.33 & 0.61 & 66.6 & 22.9 & 56.9 & 86.8 & 121.7 & 182.4 \\
\hline $128-2$ & $12: 15$ & $16: 16$ & 0.57 & 8.00 & 14.27 & 188 & 3.47 & 293.58 & 0.57 & 67.3 & 23.1 & 57.5 & 87.7 & 123.0 & 184.3 \\
\hline $129-1$ & 9:59 & $14: 02$ & 0.54 & 7.67 & 13.24 & 234 & 6.00 & 642.17 & 0.41 & 66.7 & 22.9 & 57.0 & 87.0 & 122.0 & 182.8 \\
\hline $130-2$ & $12: 38$ & $16: 43$ & 0.33 & 2.02 & 6.67 & 270 & 3.92 & 474.74 & 0.56 & 61.5 & 23.9 & 59.4 & 90.6 & 127.1 & 190.4 \\
\hline $131-1$ & $9: 12$ & $13: 17$ & 0.42 & 5.67 & 10.12 & 186 & & 682.15 & 0.58 & 65.8 & 22.6 & 56.3 & 85.8 & 120.3 & 180.3 \\
\hline $132-2$ & $12: 41$ & $16: 49$ & 0.53 & 7.63 & 13.56 & 190 & 1.87 & 799.60 & 0.49 & 62.2 & 21.4 & 53.2 & 81.1 & 113.7 & 170.4 \\
\hline $133-1$ & $10: 22$ & $13: 17$ & 0.40 & 4.79 & 8.58 & 282 & 2.14 & 191.26 & 0.57 & 61.3 & 21.1 & 52.4 & 79.9 & 112.1 & 168.0 \\
\hline $138-2$ & $12: 56$ & $17: 01$ & 0.31 & 2.11 & 6.24 & 159 & 1.23 & 212.80 & 0.60 & 52.2 & 17.9 & 44.6 & 68.0 & 95.4 & 142.9 \\
\hline $157-1$ & $7: 31$ & $11: 58$ & 0.30 & 1.71 & 5.31 & 140 & 2.50 & -8.52 & 0.61 & 30.1 & 11.4 & 28.5 & 43.4 & 60.9 & 91.2 \\
\hline $158-1$ & $8: 14$ & $12: 25$ & 0.50 & 4.39 & 9.42 & 141 & 1.73 & 130.85 & 0.64 & 32.6 & 11.2 & 27.9 & 42.5 & 59.7 & 89.4 \\
\hline $158-2$ & $12: 32$ & $16: 05$ & 0.54 & 4.32 & 9.79 & 138 & 0.82 & 254.49 & 0.82 & 31.3 & 10.7 & 26.7 & 40.8 & 57.2 & 85.6 \\
\hline $159-2$ & $13: 31$ & $17: 31$ & 0.33 & 3.41 & 7.10 & 156 & 2.05 & 40.77 & 0.39 & 33.7 & 11.6 & 28.8 & 44.0 & 61.6 & 92.4 \\
\hline $178-1$ & 8:02 & $12: 23$ & 0.46 & 2.68 & 6.91 & 162 & 0.65 & -36.62 & 0.79 & 18.2 & 6.3 & 15.6 & 23.7 & 33.3 & 49.9 \\
\hline $178-2$ & $12: 29$ & $16: 39$ & 0.52 & 2.56 & 6.98 & 166 & 1.97 & 14.31 & 0.69 & 17.9 & 6.2 & 15.3 & 23.4 & 32.8 & 49.1 \\
\hline $179-1$ & $7: 34$ & $11: 36$ & 0.53 & 3.00 & 7.71 & 181 & & 71.21 & 0.74 & 18.0 & 6.2 & 15.4 & 23.5 & 32.9 & 49.3 \\
\hline $179-2$ & $11: 42$ & $15: 52$ & 0.58 & 2.96 & 8.17 & 173 & 0.61 & -44.78 & 0.96 & 18.4 & 6.3 & 15.7 & 24.0 & 33.6 & 50.3 \\
\hline $190-1$ & $7: 26$ & $11: 36$ & 0.47 & 1.74 & 5.73 & 299 & 2.12 & -113.29 & 0.66 & 25.4 & 8.7 & 21.7 & 33.2 & 46.5 & 69.7 \\
\hline $190-2$ & $11: 45$ & $15: 55$ & 0.59 & 2.14 & 7.34 & 286 & 0.48 & -57.07 & 0.71 & 26.1 & 8.9 & 22.3 & 34.0 & 47.7 & 71.4 \\
\hline $191-1$ & $7: 30$ & $11: 37$ & 0.35 & 1.12 & 4.06 & 56 & 0.91 & -30.60 & 0.57 & 25.8 & 8.8 & 22.0 & 33.6 & 47.1 & 70.6 \\
\hline $191-2$ & $11: 43$ & $15: 59$ & 0.43 & 1.29 & 5.58 & 51 & 0.26 & 84.95 & 0.55 & 26.2 & 9.0 & 22.4 & 34.2 & 47.9 & 71.8 \\
\hline $213-1$ & $7: 49$ & $11: 47$ & 0.24 & 0.53 & 3.10 & 126 & 1.54 & 100.86 & 0.51 & 14.1 & 7.8 & 19.5 & 29.8 & 41.8 & 62.6 \\
\hline $213-2$ & $11: 48$ & $15: 48$ & 0.31 & 0.84 & 3.38 & 183 & 1.83 & -16.92 & 0.54 & 22.7 & 9.0 & 22.5 & 34.3 & 48.1 & 72.0 \\
\hline $214-1$ & $7: 46$ & $11: 46$ & 0.33 & 0.98 & 3.84 & 212 & 1.69 & -27.59 & 0.59 & 24.6 & 8.4 & 21.0 & 32.1 & 45.0 & 67.4 \\
\hline $214-2$ & $11: 52$ & $15: 56$ & 0.32 & 0.71 & 3.55 & 121 & 0.63 & -161.08 & 0.53 & 22.0 & 8.7 & 21.7 & 33.1 & 46.4 & 69.5 \\
\hline $239-1$ & $7: 23$ & $11: 45$ & 0.34 & 1.10 & 3.93 & 60 & 2.44 & 46.16 & 0.56 & 24.5 & 8.4 & 21.0 & 32.0 & 44.9 & 67.2 \\
\hline $239-2$ & $11: 50$ & $16: 31$ & 0.33 & 1.17 & 4.48 & 32 & 1.60 & 55.13 & 0.51 & 25.7 & 8.8 & 22.0 & 33.5 & 47.0 & 70.4 \\
\hline $241-1$ & $7: 25$ & $11: 33$ & 0.41 & 1.63 & 4.84 & 170 & 1.60 & -16.42 & 0.24 & 25.5 & 8.8 & 21.8 & 33.2 & 46.6 & 69.8 \\
\hline $241-2$ & $11: 39$ & $15: 43$ & 0.41 & 1.45 & 6.20 & 172 & 1.07 & 6.63 & 0.40 & 24.7 & 8.5 & 21.1 & 32.2 & 45.2 & 67.7 \\
\hline $273-1$ & $7: 38$ & $11: 48$ & 0.57 & 2.06 & 6.57 & 33 & 0.75 & -84.22 & 0.59 & 26.2 & 9.0 & 22.4 & 34.2 & 47.9 & 71.8 \\
\hline $273-2$ & $11: 52$ & $16: 42$ & 0.50 & 1.65 & 5.48 & 62 & 1.65 & 184.99 & 0.59 & 26.1 & 9.0 & 22.3 & 34.0 & 47.7 & 71.5 \\
\hline $445 \_1$ & $8: 15$ & $12: 24$ & 0.35 & 5.10 & 9.05 & 293 & 2.10 & -246.01 & 0.57 & 108.0 & 37.1 & 92.3 & 140.7 & 197.4 & 295.7 \\
\hline $445-2$ & $12: 33$ & $16: 42$ & 0.39 & 4.91 & 9.52 & 65 & 2.59 & 98.20 & 0.53 & 110.1 & 37.8 & 94.1 & 143.6 & 201.4 & 301.7 \\
\hline
\end{tabular}




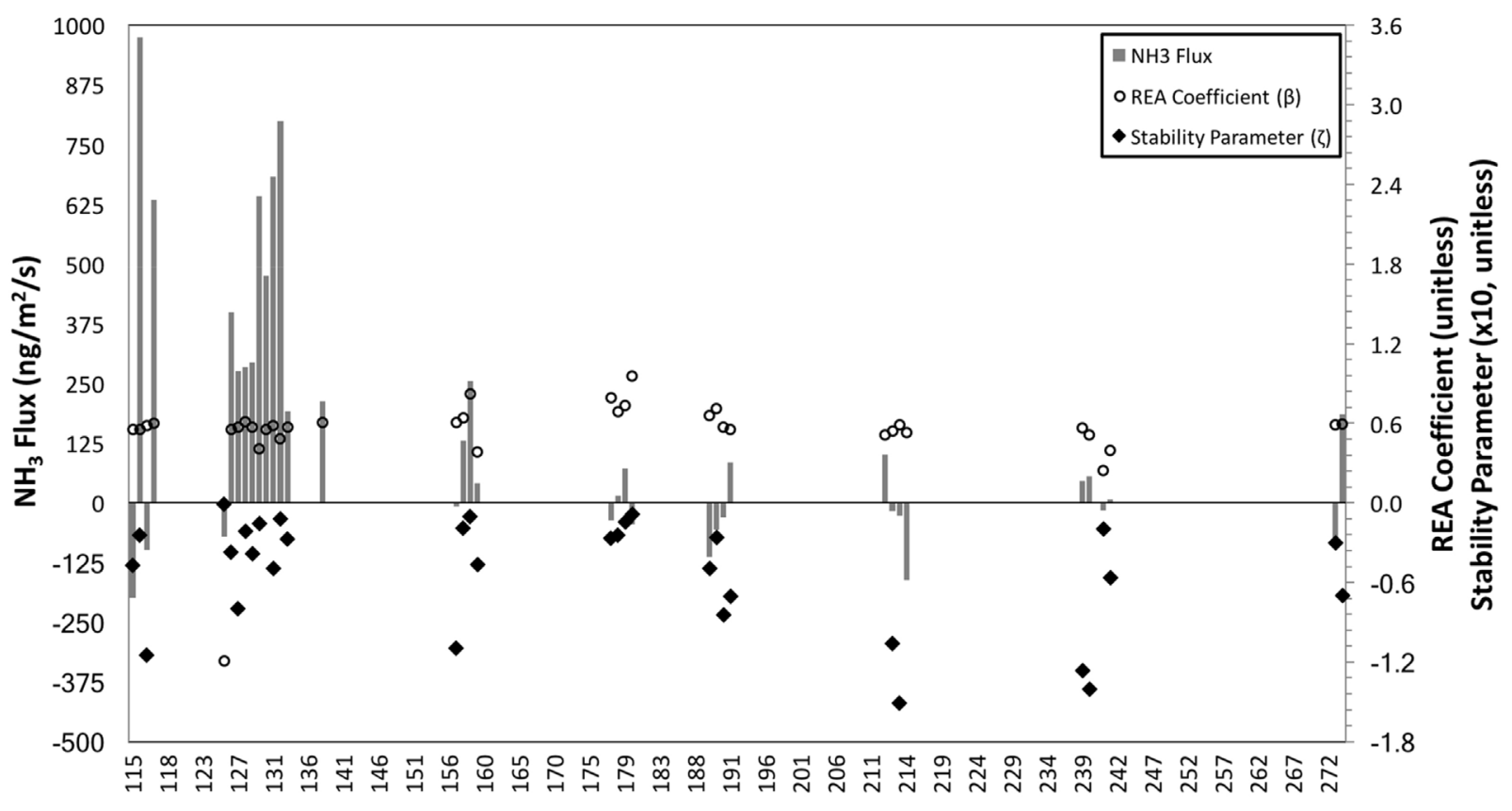

Day of Year

Fig. 5. $\mathrm{NH}_{3}$ flux and $\beta$ values for all REA sampling runs collected during the 2014 growing season.

Table 2

Summary of $\beta$ values from this study and from the literature. Standard deviations are presented where available, otherwise maximum and minimum values are reported.

\begin{tabular}{ccc}
\hline Author & Ecosystem & Reported $\beta$ \\
\hline Baker et al. (1992) & Theoretical value & 0.627 \\
This study & Corn (entire growing season) & $0.58 \pm 0.12$ \\
Tsai et al. (2012) & Marsh & $0.57 \pm 0.01$ \\
& Paddy & $0.55 \pm 0.01$ \\
& Lagoon & $0.56 \pm 0.01$ \\
Myles et al. (2007) & Grassland & $0.54 \pm 0.12$ \\
Meyers et al. (2006) & Corn (at planting) & $0.58-0.70$ \\
Zemmelink et al. (2002) & Corn (at peak LAI) & $0.32-0.98$ \\
Zhu et al. (2000) & Ocean & $0.55-0.57$ \\
\end{tabular}

No statistically significant difference between morning and afternoon samples was identified using a $t$-test at the 95\% confidence level whether the test was performed on all qualified samples or separately for qualified positive and negative fluxes. $50 \%$ of the morning samples exhibited negative fluxes compared to $22 \%$ of afternoon measurements. Of all qualified samples, mean positive flux was $233.3 \pm 203.0 \mathrm{ng} \mathrm{m}^{-2} \mathrm{~s}^{-1}$ in the morning and $260.0 \pm 253.3 \mathrm{ng} \mathrm{m}^{-2} \mathrm{~s}^{-1}$ in the afternoon. Mean negative flux was $-45.3 \pm 38.6 \mathrm{ng} \mathrm{m}^{-2} \mathrm{~s}^{-1}$ in the morning and $-78.35 \pm 74.9 \mathrm{ng} \mathrm{m}^{-2} \mathrm{~s}^{-1}$ in the afternoon. A summary of $\mathrm{NH}_{3}$ concentration, flux ranges, and REA coefficient values for the full growing season and two sub-periods is presented in Table 3.

Table 3

Values of average ambient $\mathrm{NH}_{3}$ concentrations and standard deviations, ranges of qualified $\mathrm{NH}_{3}$ fluxes, and average and standard deviation REA coefficients for the complete growing season, 32 days post planting (DOY 127-159), and the remainder of the 2014 growing season.

\begin{tabular}{cccccc}
\hline $\begin{array}{l}\text { Period } \\
(\mathrm{DOY})\end{array}$ & $\begin{array}{l}\mathrm{C}_{\mathrm{NH} 3} \\
\left(\mu \mathrm{g} \mathrm{m}^{3}\right)\end{array}$ & $\begin{array}{l}\sigma_{\mathrm{CNH3}} \\
\left(\mu \mathrm{g} \mathrm{m}^{3}\right)\end{array}$ & $\begin{array}{l}\overline{\boldsymbol{F}_{\mathrm{NH} 3}} \text { range } \\
\left(\mathrm{ng} \mathrm{m}^{-2} \mathrm{~s}^{-1}\right)\end{array}$ & $\beta$ & $\sigma_{\beta}$ \\
\hline All & 2.6 & 2.0 & $-161.1,799.6$ & 0.58 & 0.12 \\
$127-159$ & 2.70 & 1.38 & $-8.5,799.6$ & 0.57 & 0.11 \\
$160-273$ & 1.20 & 0.73 & $-161.1,185.0$ & 0.60 & 0.15 \\
\hline
\end{tabular}

This table describes all results after eliminating outlier values as described above.

Correlation between $\mathrm{NH}_{3}$ flux and environmental parameters was investigated for both sub-periods defined above. Good correlation of $\mathrm{NH}_{3}$ flux with both wind speed $(\mathrm{r}=0.54)$ and soil moisture $(\mathrm{r}=-0.75)$ was observed during DOY 127-159, while air temperature $(r=0.28)$ and soil temperature $(r=-0.024)$ were found to have weak correlation over the same period. No correlation with these parameters was found during DOY 160-273 $(\mathrm{r}<|0.1|$ for all parameters). This result suggests that localized environmental conditions have a greater impact on $\mathrm{NH}_{3}$ fluxes during the early season before canopy development. A further investigation of such correlations using DNDC modeling is presented in Balasubramanian et al. (2017).

Processes resulting in the bi-directionality of $\mathrm{NH}_{3}$ flux exhibited during DOY 160-273 are not well understood. Walker et al. (2006) reported highest deposition rates when the canopy was wet, while temperature can affect stomatal resistance and compensation point which are linked to concentrations of apoplast $\left[\mathrm{NH}_{4}{ }^{+}\right]$and $\left[\mathrm{H}^{+}\right]$ (Wu et al., 2009). Additional targeted measurements are required to quantify the effect of the canopy and canopy evapotranspiration on $\mathrm{NH}_{3}$ flux.

\subsection{Flux footprint and measurement uncertainty}

Fig. 6 presents wind roses from two REA sampling runs where the $90 \%$ flux footprint distance exceeded the study plot boundary (181.8 $\mathrm{m}$ on DOY $127-1$ and $168.0 \mathrm{~m}$ on DOY $133-1$ ). The shaded areas of the wind roses correspond to values of $\theta$ where neighboring fields were comprised of mixed crop types.

The wind rose for DOY 127-1 (Fig. 6a) shows that wind originated from the non-shaded area of the wind rose, indicating that corn was the contributor to the measured flux. However, on DOY 133-1 (Fig. 6b) wind originated from the mixed crop area in the west to northwest direction $\left(285^{\circ}<\theta<315^{\circ}\right) 32 \%$ of the time in the $4 \mathrm{~h}$ period, and was distributed along the boundary of the corn and mixed crops the remaining $68 \%$ of the time $\left(255^{\circ}<\theta<285^{\circ}\right)$. 
DOY $127-1$

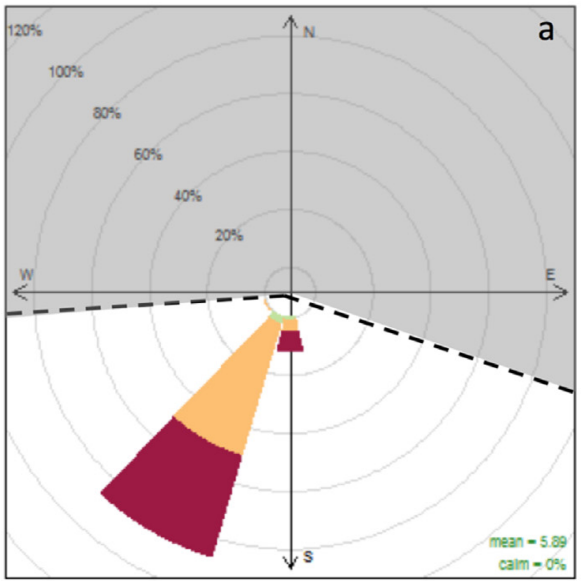

Frequency of Counts by Wind Direction (\%)
DOY $133-1$

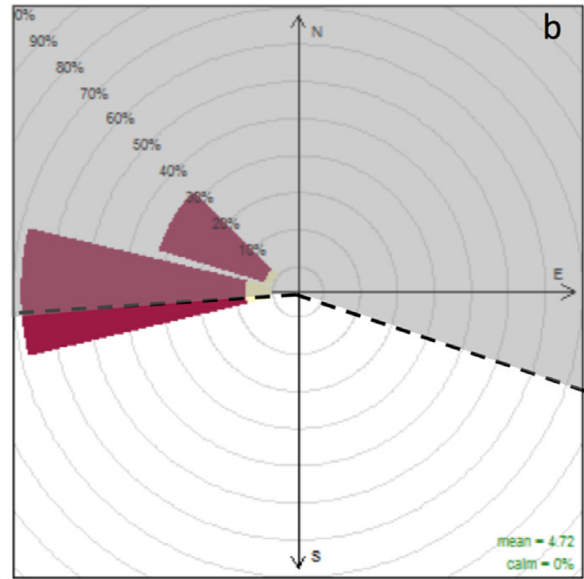

calm $-0 \%$

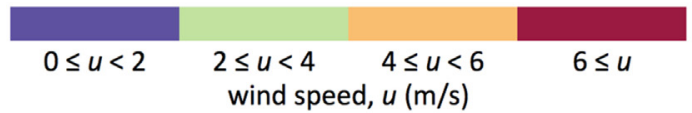

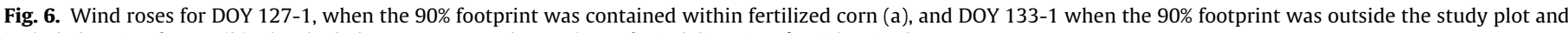
included a mix of crops (b). The shaded area corresponds to values of wind direction, $\theta$, with mixed crop types.

\section{Table 4}

Predicted underestimation of flux $\left(E_{\text {und }}\right)$ based on DeNitrification DeComposition (DNDC) model runs for environmental and field management conditions measured during the REA sampling runs where the flux footprint exceeded the boundary of the study plot but was entirely over neighboring cornfields. $E_{S}$ and $E_{N}$ are DNDC emission estimates from the study and neighboring plots, respectively. $R_{S}$ and $R_{N}$ are the relative contributions to total flux from the study and neighboring plots, respectively.

\begin{tabular}{|c|c|c|c|c|c|}
\hline $\begin{array}{l}\text { Day } \\
\text { (DOY) }\end{array}$ & $\begin{array}{l}E_{S} \\
\left(\mathrm{~kg} \mathrm{Nha}^{-1} \mathrm{~d}^{-1}\right)\end{array}$ & $\begin{array}{l}E_{N} \\
\left(\mathrm{~kg}-\mathrm{Nha}^{-1} \mathrm{~d}^{-1}\right)\end{array}$ & $\begin{array}{l}R_{S} \\
(\%)\end{array}$ & $\begin{array}{l}R_{N} \\
(\%)\end{array}$ & $\begin{array}{l}E_{\text {und }} \\
(\%)\end{array}$ \\
\hline $126-2$ & 0.21 & 0.09 & 61.8 & 38.2 & 21.8 \\
\hline $127-1$ & 0.38 & 0.09 & 58.4 & 41.6 & 31.8 \\
\hline $127-2$ & 0.38 & 0.09 & 57.7 & 42.3 & 32.3 \\
\hline $128-1$ & 0.51 & 0.10 & 58.2 & 41.8 & 33.6 \\
\hline $128-2$ & 0.51 & 0.10 & 57.6 & 42.4 & 34.1 \\
\hline 129-1 & 0.61 & 0.09 & 58.1 & 41.9 & 35.7 \\
\hline $130-2$ & 0.57 & 0.08 & 55.7 & 44.3 & 38.1 \\
\hline $131-2$ & 0.70 & 0.09 & 58.9 & 41.1 & 35.8 \\
\hline $132-2$ & 0.68 & 0.08 & 62.3 & 37.7 & 33.3 \\
\hline $138-2$ & 0.26 & 0.03 & 72.8 & 27.3 & 24.1 \\
\hline
\end{tabular}

In these example cases, DOY 127-1 was further evaluated to estimate the under-prediction of $\mathrm{NH}_{3}$ flux, while DOY 133-1 was not considered for further statistical evaluation due to contributions by mixed crop types.

The largest footprints occurred during the pre-planting and post-harvest periods due to higher average wind speed and minimal plant canopy resulting in reduced surface roughness. Further, $90 \%$ footprint distances exceeded the boundary of the study plot during the first two weeks of sampling (DOY 126-138). As described above, one flux measurement (DOY 133-1) was removed from statistical consideration during this period due to contributions from non-corn crops. Ten REA sampling runs were identified between planting and harvest where the $90 \%$ flux footprint distance exceeded the boundary of the study plot but extended over the neighboring cornfield without passing by the nearby mixed crop areas. (Table 4 ).

From Eq. (4), measured flux during the ten sampling runs where the footprint exceeded the study plot was underestimated by $32 \% \pm 5 \%$. This value describes the difference between an ideal sampling case (i.e. one in which the study plot extends uniformly and infinitely in all directions) and the actual case with non-uniform fields of finite size. Because the neighboring cornfield was fertilized 40 days earlier than the study plot, its expected peak $\mathrm{NH}_{3}$ emissions occurred before any measurements at the study plot were made. Therefore, during the measurement period just after fertilization of the measurement plot, and in cases where the flux footprint extended over that neighboring field, the contributed flux from the neighboring field was lower than the flux contributed by the study plot alone, resulting into a lower average flux. Having established that DNDC can effectively capture spatial and temporal variation of $\mathrm{NH}_{3}$ fluxes as a function of environmental and farm management parameters from the measurement-modeling comparison study by Balasubramanian et al. (2017), using DNDC modeled estimates provided a method to quantify uncertainty ranges for the field measurements.

\subsection{Comparison of results with other studies}

As previously mentioned, Walker et al. (2013) studied a corn canopy in North Carolina, USA using the modified Bowen ratio to measure $\mathrm{NH}_{3}$ fluxes over two-hour averaging periods. They reported a similar temporal profile with highest emissions occurring in the first 30 days post-fertilization. The field studied by Walker et al. was fertilized ( $20 \mathrm{~kg}-\mathrm{N} \mathrm{ha}{ }^{-1}$ as injected ammonium polyphosphate) and planted with corn from DOY 108-113. A subsequent side-dress application ( $134 \mathrm{~kg}-\mathrm{N} \mathrm{ha}^{-1}$ as UAN) was applied from DOY 145-149.

Walker et al. (2013) divided fluxes into two periods: the first 31 days following side-dress fertilizer application (DOY 149-180) and the remaining 32 days (DOY 181-213). Reported fluxes from Walker et al. (2013) are presented in Table 5 with results from this study presented in similarly divided time periods relative to the initial date of fertilization.

Though the general trend measured in this study is similar to results by Walker et al., the maximum positive flux reported by Walker et al. (6906 $\mathrm{ng} \mathrm{m}^{-2} \mathrm{~s}^{-1}$ ) is higher than in this study (799.6 $\mathrm{ng} \mathrm{m}^{-2} \mathrm{~s}^{-1}$ ) even if we correct for the underestimation predicted using DNDC modeling. Similarly, Walker et al. reported greater negative fluxes $\left(-230.4 \mathrm{ng} \mathrm{m}^{-2} \mathrm{~s}^{-1}\right)$ compared to the corresponding time period in this study $\left(-44.8 \mathrm{ng} \mathrm{m}^{-2} \mathrm{~s}^{-1}\right)$. The differences in measured maxima and minima between Walker et al. 
Table 5

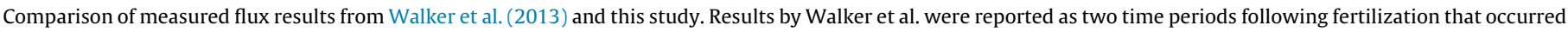
twice during the crop season. Data from this study have been similarly reported.

\begin{tabular}{|c|c|c|c|c|c|c|}
\hline & Location & DOY & Days post- final fertilization & Mean Flux \pm std. $\operatorname{dev}\left(\mathrm{ng} \mathrm{m}^{-2} \mathrm{~s}^{-1}\right)$ & Max. Flux $\left(\mathrm{ng} \mathrm{m}^{-2} \mathrm{~s}^{-1}\right)$ & Min. Flux $\left(\mathrm{ng} \mathrm{m}^{-2} \mathrm{~s}^{-1}\right.$ \\
\hline \multirow{2}{*}{ Walker et al. (2013) } & Lillington, NC & $149-180$ & $0-31$ & $339.2 \pm 601.7$ & 6906 & -42.5 \\
\hline & & $181-213$ & $32-64$ & $61.4 \pm 10.2$ & 3125.4 & -230.4 \\
\hline \multirow[t]{3}{*}{ This study } & Urbana, IL & 127-159 & $1-33$ & $358.6 \pm 249.7$ & 799.6 & -8.5 \\
\hline & & $160-180$ & $34-54$ & $1.03 \pm 53.6$ & 71.2 & -44.8 \\
\hline & & $160-273$ & $34-147$ & $-2.03 \pm 91.2$ & 100.9 & -161.1 \\
\hline
\end{tabular}

Table 6

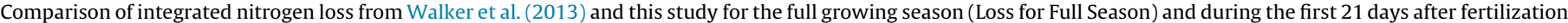
(Loss for First 21 days).

\begin{tabular}{|c|c|c|c|c|}
\hline & \multicolumn{2}{|c|}{ Loss for the Full Growing Season } & \multicolumn{2}{|c|}{ Loss in the First 21 days } \\
\hline & Mean (\%) & Median (\%) & Mean (\%) & Median (\%) \\
\hline Walker et al. (2013) & 8.3 & 6.1 & 4.5 & 3.4 \\
\hline This study & 10.9 & 4.7 & 4.6 & 3.7 \\
\hline
\end{tabular}

and this study may originate in differences in measurement methods, averaging times, field management practices, climatic and soil characteristics and background conditions.

We estimated $\mathrm{NH}_{3}$ loss relative to fertilizer applied for the full corn growing season (Loss for the Full Season) and during the first 21 days after fertilization (Loss in the First 21 days) using mean and median $\mathrm{NH}_{3}$ flux values for each time period with timescale characterization similar to that reported by Walker et al. (2013) (Table 6).

Though different field management practices were used, both fields were treated with a urease inhibitor concurrently with fertilization. $\mathrm{NH}_{3}$ loss during the periods presented in Table 6 is similar between these studies, with differences likely attributable to experimental error. $\mathrm{NH}_{3}$ Loss in the First 21 days after fertilization accounts for $79 \%$ of Loss for the Full Growing Season in this study compared to $56 \%$ as reported by Walker et al. This difference is attributable to the longer duration of this study with more observations during low-emission periods and highlights the importance of early-season emissions in the overall $\mathrm{NH}_{3}$ emission profile. Future research should continue to focus on this early-season period, when the largest loss of $\mathrm{NH}_{3}$ occurs.

In considering our results with Walker et al. (2013), we also expect differences due to different management practices. However, it is not straightforward to identify the relevant importance of such differences given that management practices, temporal resolution of measurements, and environmental conditions also have an effect. Quantification of the relative impact of such factors requires further detailed studies designed to control for such conditions. Such uncertainty can be resolved with systematic measurement studies that involve carefully controlled inter-comparisons in similar environments and measurementmodeling studies for a broad range of environmental conditions and farm management practices.

\section{Summary and conclusions}

$\mathrm{NH}_{3}$ flux above a corn canopy in central Illinois, USA was measured for the duration of the 2014 corn-growing season, including additional post-season background measurements collected during March 2015. High variability (coefficient of variation $=1.93$ ) in $\mathrm{NH}_{3}$ flux was observed throughout the season. Using median season-long flux measurements to estimate nitrogen loss, $79 \%$ of total loss was observed in the first 21 days post-fertilization. The greatest fluxes toward the atmosphere occurred in the first 30 days following fertilization when compared with the remainder of the season. Results from this field campaign exhibit a temporal pattern of emission similar to that reported by Walker et al. (2013) over a corn canopy in North Carolina, where highest emissions were observed during a 30 day period following fertilization. However, maximum and minimum fluxes reported by Walker et al. were both greater in magnitude than those measured in this study (764\% and $414 \%$, respectively). Further studies are required to understand the cause of these differences in measured $\mathrm{NH}_{3}$ emissions from fertilized fields and for measurement method inter-comparison.

This research represents the first reported measurements of $\mathrm{NH}_{3}$ flux over a corn canopy in the Midwest National Climate Assessment climate region, where $\mathrm{NH}_{3}$ emissions are dominated by chemical fertilizer application. Such measurements are important to improve understanding of $\mathrm{NH}_{3}$ emissions from this important, yet understudied ecosystem, particularly in the Midwestern USA. Further, the data presented in this study are needed to assess closure between measurements and models of $\mathrm{NH}_{3}$ emissions for use in biogeochemical and chemical transport models to understand the impact of agricultural $\mathrm{NH}_{3}$ emissions on air quality and the global nitrogen cycle.

\section{Acknowledgements}

This study was funded by the National Science Foundation, Award Numbers AGS 12-36814 and 12-33458 with an accompanying research experience for undergraduates (REU). The views reported here do not necessarily represent the views of the funding agency. The authors gratefully acknowledge the Energy Biosciences Institute and Mr. Timothy Mies and Mr. Collin Reeser for facilitating the use of the Energy Farm for the field campaign. We also thank Ms. Brenda Riney of the NADP CAL for sample analysis.

\section{References}

Appel, K.W., Foley, K.M., Bash, J.O., Pinder, R.W., Dennis, R.L., Allen, D.J., Pickering K., 2011. A multi-resolution assessment of the community multiscale air quality (CMAQ) model v4.7 wet deposition estimates for 2002-2006. Geosci. Model Dev. 4, 357-371.

Baker, J.M., Norman, J.M., Bland, W.L., 1992. Field-scale application of flux measurement by conditional sampling. Agr. For. Meteorol. 62, 31-52.

Balasubramanian, S., Koloutsou-Vakakis, S., McFarland, D.M., Rood, M.J., 2015. Reconsidering emissions of ammonia from chemical fertilizer usage in Midwest USA. J. Geophys. Res. Atmos. 120, 6232-6246.

Balasubramanian, S., Nelson, A., Koloutsou-Vakakis, S., Lin, J., Rood, M.J., Myles, L.T. Bernacchi, C., 2017. Evaluation of DeNitrification DeComposition model for estimating ammonia fluxes from chemical fertilizer application. Agr. For. Meteorol. 237, 123-134

Baldocchi, D.D., Hincks, B.B., Meyers, T.P., 1988. Measuring biosphere-atmosphere exchanges of biologically related gases with micrometeorological methods. Ecology 69, 1331-1340.

Bash, J.O., Walker, J.T., Katul, G.G., Jones, M.R., Nemitz, E., Robarge, W.P., 2010. Estimation of in-canopy ammonia sources and sinks in a fertilized zea mays field. Environ. Sci. Technol. 44, 1683-1689. 
Bowling, D.R., Delany, A.C., Turnipseed, A.A., Baldocchi, D.D., Monson, R.K., 1999. Modification of the relaxed eddy accumulation technique to maximize measured scalar mixing ratio differences in updrafts and downdrafts. J. Geophys. Res. 104, 9121-9133.

Businger, J., Oncley, S.P., 1990. Flux measurement and conditional sampling. J. Atmos. Ocean Technol. 7, 349-352.

Carslaw, D.C., Ropkins, K., 2012. openair-an R package for air quality data analysis. Environ. Modell. Softw. 27-28, 52-61.

Conant, R.T., Berdanier, A.B., Grace, P.R., 2013. Patterns and trends in nitrogen use and nitrogen recovery efficiency in world agriculture. Global Biogeochem. Cycles 27, 558-566.

Cooter, E.J., Bash, J.O., Walker, J.T., Jones, M.R., Robarge, W., 2010. Estimation of NH3 bi-directional flux from managed agricultural soils. Atmos. Environ. 44, 2107-2115.

Desjardins, R.L., 1972. A Study of Carbon-dioxide and Sensible Heat Fluxes Using the Eddy Correlation Technique. PhD Dissertation. Cornell University, 189 pp.

Duyzer, J., 1994. Dry deposition of ammonia and ammonium aerosols over heathland. J. Geophys. Res. 99, 18757.

Erisman, J.W., Galloway, J.N., Seitzinger, S., Bleeker, A., Dise, N.B., Petrescu, A.M., Leach, A.M., de Vries, W., 2013. Consequences of human modification of the global nitrogen cycle. Philos. Trans. R. Soc. B 368, 20130116.

Fotiadi, A.K., Lohou, F., Druilhet, A., Serça, D., Said, F., Laville, P., Brut, A., 2005. Methodological development of the conditional sampling method. Part II: quality control criteria of relaxed eddy accumulation flux measurements. Bound-Lay. Meteorol. 117, 577-603.

Galloway, J.N., Townsend, A.R., Erisman, J.W., Bekunda, M., Cai, Z., Freney, J.R., Martinelli, L.A., Seitzinger, S.P., Sutton, M.A., 2008. Transformation of the nitrogen cycle: recent trends, questions, and potential solutions. Science 320, 889-892.

Gilliland, A.B., Appel, K., Pinder, R.W., Dennis, R.L., 2006. Seasonal NH3 emissions for the continental united states: inverse model estimation and evaluation. Atmos. Environ. 40, 4986-4998.

Google Maps. 2016. 40.0628, -88.1961. Retrieved 21 May, 2016 from https:// www.google.com/maps/place/40\%C2\%B003'46.1\%22N+88\%C2\%B011'46. 0\%22W/@40.0628,88.1977286,530m/

data $=$ !3m2! $1 \mathrm{e} 3 ! 4 \mathrm{~b} 1 ! 4 \mathrm{~m} 5 ! 3 \mathrm{~m} 4 ! 1 \mathrm{~s} 0 \times 0: 0 \times 0 ! 8 \mathrm{~m} 2 ! 3 \mathrm{~d} 40.0628 ! 4 \mathrm{~d}-88$ 1961 ?hl=en.

Grönholm, T., Haapanala, S., Launiainen, S., Rinne, J., Vesala, T., Rannik, Ü., 2008. The dependence of the $\beta$ coefficient of REA system with dynamic deadband on atmospheric conditions. Environ. Pollut. 152, 597-603.

Green, M.C., Chen, L.W., DuBois, D.W., Molenar, J.V., 2012. Fine particulate matter and visibility in the Lake Tahoe Basin: chemical characterization, trends, and source apportionment. J. Air Waste Manage. 62, 953-965.

Harper, L.A., Sharpe, R.R., 1995. Nitrogen dynamics in irrigated corn: soil-plant nitrogen and atmospheric ammonia transport. Agron. J. 87, 669-675.

He, Z., Wright, L.P., Zhang, L., 2013. Model-measurement comparison of ammonia Bi-directional air-surface exchange fluxes over agricultural fields. Atmos. Clim. Sci. 2013, 465-474.

Hensen, A., Nemitz, E., Flynn, M.J., Blatter, A., Jones, S.K., Sørensen, L.L., Hensen, B., Pryor, S.C., Jensen, B., Otjes, R.P., Cobussen, J., Loubet, B., Erisman, J.W., Gallagher, M.W., Neftel, A., Sutton, M.A., 2009. Inter-comparison of ammonia fluxes obtained using the Relaxed Eddy Accumulation technique. Biogeosciences 6, 2575-2588.

ISWS (2016) Prairie Research Institute, July 2014 Weather Observations for Champaign-Urbana, Illinois. http://www.isws.illinois.edu/atmos/statecli/ urbana/urbana-monthly-2014.htm (Accessed May 20, 2016).

Kljun, N., Calanca, P., Rotach, M.W., Schmid, H.P., 2004. A simple parameterisation for flux footprint predictions. Bound-Lay. Meteorol. 112, 503-523.

Kormann, R., Meixner, F.X., 2001. An analytical footprint model for non-neutral stratification. Bound-Lay. Meteorol. 99, 207-224.

Li, C.S., 2000. Modeling trace gas emissions from agricultural ecosystems. Nutr. Cycl. Agroecosyst. 58, 259-276.

Mattsson, M., Herrmann, B., David, M., Loubet, B., Riedo, M., Theobald, M.R., Sutton, M.A., Bruhn, D., Neftel, A., Schjoerring, J.K., 2008. Temporal variability in bioassays of ammonia exchange potential in relation to plant and soil nitrogen parameters in intensively managed grassland. Biogeosciences 6, 171-179.

Meyers, T., Luke, W., Meisinger, J., 2006. Fluxes of ammonia and sulfate over maize using relaxed eddy accumulation. Agr. For. Meteorol. 136, 203-213.

Myhre, G., Shindell, D., Bréon, F.M., Collins, W., Fuglestvedt, J., Huang, J., Koch, D., Lamarque, J.-F., Lee, D., Mendoza, B., Nakajima, T., Robock, A., Stephens, G., Takemura, T., Zhang, H., 2013. Anthropogenic and natural radiative forcing. In: Stocker, T.F., Qin, D., Plattner, G.-K., Tignor, M., Allen, S.K., Boschung, J., Nauels, A., Xia, Y., Bex, V., Midgley, P.M. (Eds.), Climate Change 2013: The Physical Science Basis. Contribution of Working Group I to the Fifth Assessment Report of the Intergovernmental Panel on Climate Change. Cambridge University Press, Cambridge, United Kingdom and New York, NY, USA.

Myles, L., Meyers, T.P., Robinson, L., 2007. Relaxed eddy accumulation measurements of ammonia, nitric acid, sulfur dioxide and particulate sulfate dry deposition near Tampa, FL, USA. Environ. Res. Lett. 2, 034004.

Myles, L., Kochendorfer, J., Heuer, M.W., Meyers, T.P., 2011. Measurement of trace gas fluxes over an unfertilized agricultural field using the flux-gradient technique. J. Environ. Qual. 40, 1359-1365.

NADP (2008) Standard Operating Procedure for the Determination of Passive Ammonia (Phenolate) by Flow Injection Analysis, SOP Number: AN-0022, Revision 0.0
NADP (2012) Standard Operating Procedure for Preparation and Extraction of URG Denuders. SOP Number PR-4074, Revision 1.1.

NADP (2013) Standard Operating Procedure for Ambient Ammonia Using Radiello-Type Passive Samplers. SOP Number SS-4070, Revision 5.1.

Neirynck, J., Ceulemans, R., 2008. Bidirectional ammonia exchange above a mixed coniferous forest. Environ. Pollut. 154, 424-438.

Nemitz, E., Milford, C., Sutton, M.A., 2001. A two-layer canopy compensation point model for describing bi-directional biosphere-atmosphere exchange of ammonia. Q. J. R. Meteorol. Soc. 127, 815-833.

Norman, M., Spirig, C., Wolff, V., Trebs, I., Flechard, C., Wisthaler, A., Schnitzhofer, R., Hansel, A., Neftel, A., 2009. Intercomparison of ammonia measurement techniques at an intensively managed grassland site (Oensingen, Switzerland). Atmos. Chem. Phys. 9, 2635-2645.

Paulot, F., Jacob, D.J., Pinder, R.W., Bash, J.O., Travis, K., Henze, D.K., 2014. Ammonia emissions in the United States, European Union, and China derived by high-resolution inversion of ammonium wet deposition data: interpretation with a new agricultural emissions inventory (MASAGE_NH3). J. Geophys. Res.-Atmos. 119, 4343-4364.

Phillips, S.B., Arya, S.P., Aneja, V.P., 2004. Ammonia flux and dry deposition velocity from near-surface concentration gradient measurements over a grass surface in North Carolina. Atmos. Environ. 38, 3469-3480.

R Core Team, 2013. R: A Language and Environment for Statistical Computing. R Foundation for Statistical Computing, Vienna, Austria http://www.R-project. org/.

RStudio Team, 2015. RStudio: Integrated Development for R. RStudio, Inc., Boston, MA URL http://www.rstudio.com/.

Raupach, M.R., 1994. Simplified expressions for vegetation roughness length and zero-plane displacement as functions of canopy height and area index. Bound-Lay. Meteorol. 71, 211-216.

Sommar, J., Zhu, W., Shang, L., Feng, X., Lin, C.-J., 2013. A whole-air relaxed eddy accumulation measurement system for sampling vertical vapour exchange of elemental mercury. Tellus B 65, 19940.

Sommer, S.G., Jensen, C., 1994. Ammonia volatilization from urea and ammoniacal fertilizers surface-applied to winter wheat and grassland. Fert. Res. 37, 85-92.

Sun, K., Tao, L., Miller, D.J., Zondlo, M.A., Shonkwiler, C.N., Nash, C., Ham, J.M., 2015 Open-path eddy covariance measurements of ammonia fluxes from a beef cattle feedlot. Agr. For. Meteorol. 213, 193-202.

Sutton, M.A., Nemitz, E., Erisman, J.W., Beier, C., Bahl, K.B., Cellier, P., de Vries, W., Cotrufo, F., Skiba, U., Di Marco, C., Jones, S., Laville, P., Soussana, J.F., Loubet, B., Twigg, M., Famulari, D., Whitehead, J., Gallagher, M.W., Neftel, A., Flechard, C.R., Herrmann, B., Calanca, P.L., Schjoerring, J.K., Daemmgen, U., Horvath, L., Tang, Y.S., Emmett, B.A., Tietema, A., Penuelas, J., Kesik, M., Brueggemann, N., Pilegaard, K., Vesala, T., Campbell, C.L., Olesen, J.E., Dragosits, U., Theobald, M.R., Levy, P., Mobbs, D.C., Milne, R., Viovy, N., Vuichard, N., Smith, J.U., Smith, P., Bergamaschi, P., Fowler, D., Reis, S., 2007. Challenges in quantifying biosphere-atmosphere exchange of nitrogen species. Environ. Pollut. 150, $125-139$.

Tsai, J.-L., Tsuang, B.-J., Kuo, P.-H., Tu, C.-Y., Chen, C.-L., Hsueh, M.-T., Lee, C.-S., Yao, M.-H., Hsueh, M.-L., 2012. Evaluation of the relaxed eddy accumulation coefficient at various wetland ecosystems. Atmos. Environ. 60, 336-347.

UI, 2009. Illinois Agronomy Handbook, 24th ed. University of Illinois Extension.

USDOC-NOAA, 2013 Regional Climate Trends and Scenarios for the U.S. National Climate Assessment Part 3. Climate of the Midwest U.S., NOAA Technical Report NESDIS 142-3, Washington, D.C., January 2013.

USEPA (2011), Reactive Nitrogen in the United States: An Analysis of Inputs, Flows, Consequences, and Management Options. Available from: http://www.epa. gov/sab. Last accessed January 2015.

USEPA (2012), National Ambient Air Quality Standards, Available from: http:// www.epa.gov/air/criteria.html. Last accessed January 2015.

USEPA (2015), The 2011 National Emissions Inventory, Available from: http:// www.epa.gov/ttnchie1/net/2011inventory.html. Last accessed September 2015.

Walker, J.T., Robarge, W.P., Wu, Y., Meyers, T.P., 2006. Measurement of bi-directional ammonia fluxes over soybean using the modified Bowen-ratio technique. Agr. For. Meteorol. 138, 54-68.

Walker, J.T., Jones, M.R., Bash, J.O., Myles, L., Meyers, T., Schwede, D., Herrick, J., Nemitz, E., Robarge, W., 2013. Processes of ammonia air-surface exchange in a fertilized Zea mays canopy. Biogeosciences 10, 981-998.

Wu, Y., Walker, J., Schwede, D., Peterslidard, C., Dennis, R., Robarge, W., 2009. A new model of bi-directional ammonia exchange between the atmosphere and biosphere: ammonia stomatal compensation point. Agric. For. Meteorol. 149 (2), 263-280, http://dx.doi.org/10.1016/j.agrformet.2008.08.012.

Wyngaard, J.C., Coté, O.R., 1972. Cospectral similarity in the atmospheric surface layer. Q. J. R. Meteorol. Soc. 98, 590-603.

Zemmelink, H.J., Gieskes, W.W.C., Klaassen, W., de Groot, H.W., de Baar, H.J.W., Dacey, J.W.H., Hintsa, E.J., McGillis, W.R., 2002. Simultaneous use of relaxed eddy accumulation and gradient flux techniques for the measurement of sea-to-air exchange of dimethyl sulphide. Atmos. Environ. 36, 5709-5717.

Zeri, M., Anderson-Teixeira, K., Hickman, G., Masters, M., DeLucia, E., Bernacchi, C.J., 2011. Carbon exchange by establishing biofuel crops in Central Illinois. Agr. Ecosyst. Environ. 144, 319-329.

Zhu, T., Pattey, E., Desjardins, R.L., 2000. Relaxed eddy-accumulation technique for measuring ammonia volatilization. Environ. Sci. Technol. 34, 199-203. 